\title{
DIGITAL VS. TRADITIONAL MEDIA JOURNALISTS: SOCIODEMOGRAPHIC CHARACTERISTICS AND EXTERNAL AND INTERNAL THREATS TO THEIR AUTONOMY
}

\author{
Periodistas de medios digitales vs. medios \\ tradicionales: características sociodemográficas y \\ amenazas externas e internas a su autonomía
}

Rosa Berganza, Carlos Arcila-Calderón and Beatriz Herrero-Jiménez

Nota: Este artículo puede leerse traducido al español en:

http://www.elprofesionaldelainformacion.com/contenidos/2016/mar/04_esp.pdf
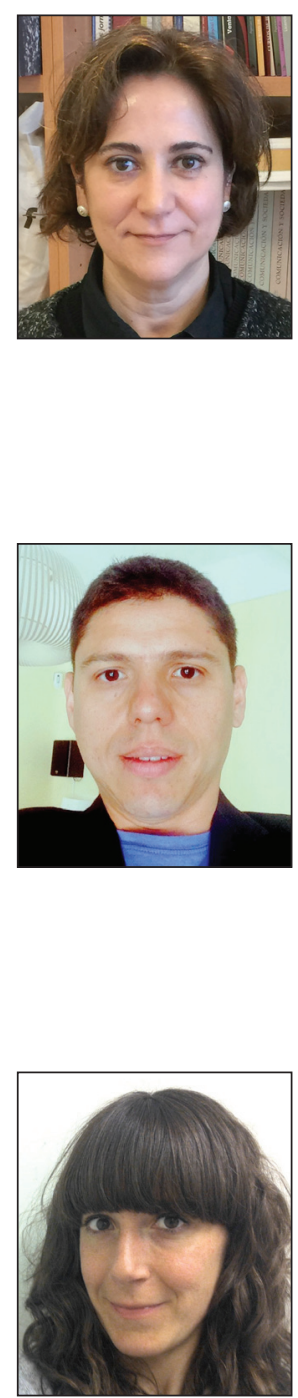

Rosa Berganza, professor at Universidad Rey Juan Carlos, has an extensive international comparative research experience in the study of journalism and political communication. She is expert in applied content analysis methodology and surveys. Prof. Berganza has leaded and collaborated on several projects funded by the European Commission as Infocore (project ID: 613308, 7th Framework Program) and Mediated Political Populism for Democratic Politics (Cost Action IS1308). She is part of Nepocs (Network of European Political Communication Scholars), and the Worlds of Journalism Study Team. Another relevant aspect of her work refers to gender aspects in media and the implementation of gender perspective in the media and in research institutions.

http://orcid.org/0000-0001-9862-2550

Universidad Rey Juan Carlos Camino del Molino, s/n. 28943 Fuenlabrada, Madrid, Spain rosa.berganza@urjc.es

Carlos Arcila-Calderón, lecturer at University of Salamanca, has a European PhD in communication, social change, and development from the Universidad Complutense de Madrid and a master's degree in journalism from the Universidad Rey Juan Carlos (URJC). He is the editor of the Anuario electrónico de estudios en comunicación social: Disertaciones; the author of over 40 scientific articles in prestigious journals; and the author of five books on the subject of communication and technologies. He has taught at the Universidad del Rosario (Colombia), Universidad del Norte (Colombia), Universidad de Los Andes (Venezuela), and was a research associate of the Universidad Católica Andrés Bello (Venezuela). He has been a visiting scholar at the Universidad Nacional de Educación a Distancia (Spain), Universidad de la Sabana (Colombia), Universidad Mayor (Chile), and Universidade Estadual Paulista (Brazil). http://orcid.org/0000-0002-2636-2849

Universidad de Salamanca, Campus Miguel de Unamuno, Edificio FES Avda. Francisco Tomás y Valiente, s/n. 37007 Salamanca, Spain carcila@usal.es

Beatriz Herrero-Jiménez is a visiting professor at the Universidad Rovira $i$ Virgili in Tarragona. She works as a researcher and adviser of the research project, Infocore: The role of media in violent conflict founded under the $7^{\text {th }}$ Framework Programme of the European Commission. She has been honorary collaborator of the Universidad Complutense de Madrid where she conducted her doctoral thesis. Her main research interests include the analysis of media discourse, media, and gender. http://orcid.org/0000-0002-7475-0782

Universitat Rovira i Virgili, Facultat de Lletres, Departament d'Estudis de Comunicació Campus Catalunya. Avda. Catalunya, 35. 43002 Tarragona, Spain beatriz.herrero.jimenez@gmail.com 


\begin{abstract}
Born-digital media is influenced by many factors. This study compares the perceptions of digital and traditional (newspaper, radio, TV, news agencies, etc.) journalists and investigates their perception of threats to their professions. This paper shows data from a national survey (probabilistic, stratified by type of outlet and region) to 390 journalists in Spain between March 2014 and May 2015. Reporters were surveyed about their differing influences (political, economic, organizational, professional routines, and reference groups) in their jobs. Even where there are clear socio-demographic differences, data shows that, except for the influence of reference groups, all journalists hold similar perceptions. Theoretical and practical implications are discussed.
\end{abstract}

\title{
Keywords
}

Journalists; Journalistic routines; Online media; Traditional media; Professional autonomy; Perceived influences.

\section{Resumen}

El surgimiento de medios digitales nativos y su consecuente exposición hacia diversas fuentes de influencia, hacen necesario conocer si la percepción de las y los nuevos periodistas sobre las posibles amenazas a su autonomía profesional difiere de la de sus compañeros/as de medios tradicionales (prensa, radio, TV, agencias, etc.). Este artículo muestra los datos de una encuesta nacional (representativa, estratificada por tipo de medio y comunidad autónoma) a 390 periodistas españoles entre marzo de 2014 y mayo de 2015, a quienes se les consultó sobre las influencias políticas, económicas, organizativas, de rutinas profesionales y de grupos de referencia, que perciben en su trabajo. A pesar de que existen claras diferencias sociodemográficas, los resultados muestran que, salvo en el caso de las influencias de los grupos de referencia, existe una percepción homogénea de los diferentes factores modelados entre ambos tipos de periodistas. Se discuten las implicaciones teóricas y prácticas.

\section{Palabras clave}

Periodistas; Rutinas periodísticas; Medios digitales; Medios tradicionales; Autonomía profesional; Influencias percibidas.

Berganza, Rosa; Arcila-Calderón, Carlos; Herrero-Jiménez, Beatriz (2016). "Digital vs. traditional media journalists: sociodemographic characteristics, and external and internal threats to their autonomy". El profesional de la información, v. 25, n. 2, pp. 179-187.

http://dx.doi.org/10.3145/epi.2016.mar.04

\section{Introduction}

Autonomy remains one of the unachieved ideals of the journalism profession (Deuze, 2005; Singer, 2007). This autonomy, which can be defined as the capacity of journalists to make personal decisions without being affected by external and internal influences (Beam, 1990), is key when we take into account the social function and service of journalism as well as its importance to guarantee pluralism (Kunelius, 2007; Relly; González-de-Bustamante, 2014).

It is clear, however, that the work of journalists is affected by multiple forces of influence that often operate simultaneously (Hanitzsch et al., 2010; Reich; Hanitzsch, 2013; Plaisance; Skewes; Hanitzsch, 2012). These influences vary across media systems and diachronically within the same country, and even within the same organization. The characteristics of the Spanish media system, theorized within the polarized pluralist model, include high political parallelism and external pluralism (Hallin; Mancini, 2004; Humanes; Martínez-Nicolás; Saperas-Lapiedra, 2013; Roses; FariasBatlle, 2013), which undoubtedly reflects the presence of greater influence in journalism in comparison to countries that follow a liberal model.

The absence of autonomy in Spain has been confirmed by journalists themselves. In fact, according to the 2013 report of the Madrid Press Association, 79.3\% of Spanish journalists claimed to have received some kind of pressure at work. Surveyed journalists pointed out that this pressure mostly comes from the media company for which they work (76.1\%), but also from political authorities (23.1\%) (APM, 2013).

The Spanish media landscape is experiencing a period of transformation as a consequence of the economic crisis that began in 2008 and the structural crisis of the business model of media companies, which was mainly triggered by the new digital scenario (APM, 2013; Casero-Ripollés; CullellMarch, 2013; Díaz-Nosty, 2011; Guallar, 2013). The deterioration of the media industry has involved drastic drops in profits, redundancy and dismissal schemes, disappearance of media companies and increased job insecurity. Although we have no accurate data, the Madrid Press Association estimates that the number of jobs lost in the media sector (not just journalists) and of defunct media companies between 2008 and 2013 is 9,471 and 284, respectively (APM, 2013).

In this new digital ecosystem, entrepreneurial journalism appears as a response to the difficult employment situation (Casero-Ripollés; Cullell-March, 2013; Martínez-Gutiérrez, 2013). The reduction of obstacles in entering the journalism business market, thanks to digital technologies, has led to the emergence of new born-digital media in Spain, mostly directed by veteran journalists and young professionals who cannot find a place in traditional media. Between 2008 and 2013, at least 297 new digital media outlets were created by journalists (APM, 2013). 
There is no doubt that this type of entrepreneurial journalism requires some transformation with regards to traditional journalism in Spain. The arrival of this new media to a landscape characterized by great media concentration (Humanes; Martínez-Nicolás; Saperas-Lapiedra, 2013), a strong hierarchy, (Agarwal; Barther, 2015) and historical ties to the political and economic powers (Hallin; Mancini, 2004), may also involve the emergence of a new type of journalism, different professional features, the possibility of more autonomy, and the perception of different influences.

This article discusses the differences in perception between journalists working with traditional media and those working with born-digital media, in order to establish whether the emergence of a new business environment may also mean the emergence of a new media logic (Dahlgren, 1996) and, as a consequence, the transformation of the qualities of the journalistic work.

\section{Perceived influences}

In recent years, empirical academic research on the multilevel structure of influences in journalism has made significant progress (Hanitzsch et al., 2010; Hanitzsch; Mellado, 2011; Plaisance et al.; 2012: Mellado; Humanes, 2012; Relly; González-de-Bustamante, 2014; Relly et al., 2015). Most of these analyses are based on the theoretical framework of Shoemaker and Reese (1996), who developed a model of hierarchy of influences consisting of five nested levels. At the center of this model is the individual, which consists of the background and professional experience of journalists. The next layer of influence comes from media routines, i.e. the journalist's practices. This layer of influence is in turn surrounded by the media organization: their structures, objectives, and roles. The following nested level contains the extra-media, which includes information sources, social institutions, and the economic environment. The final level is the ideological one, which refers to government and economic structures.

The theoretical alternatives to this model (Ettema; Whitney; Wackman, 1987; Preston, 2009; Voakes, 1997) include similar sources of influence that are often located on different levels, with the exception of the individual level, on which everyone agrees. There is not an easily quantified amount of influence that each of these sources has on the news production process. The academic literature oscillates between:

- the importance of individual predispositions (Flegel; Chaffee, 1971);

- the organizational forces of the profession (Altmepeen, 2008; Esser, 1998);

- the relevance of the economic imperatives (Benson; Hallin, 2007; McManus, 2009);

- the political determinants (Czepek; Hellwig; Novak, 2009; Hallin; Mancini, 2004).

In the absence of a consistent pattern regarding the dimensional structure of influences and their relative importance, Hanitzsch et al. (2010) carried out one of the first largescale studies on how journalists perceive influences on their work. Based on the survey responses of a sample of 1,700 journalists from 17 countries, Hanitzsch et al. summarized the perceived sources of influence using six dimensions:

- organizational;

- professional;

- procedural;

- political;

- economic;

- reference groups.

The first three dimensions are perceived to be the most influential in journalists' work. Continuing with this study, Hanitzsch and Mellado (2011) discovered the differences in perception between countries were mainly explained by variance in political and economic influences.

In Spain, the media system has been closely linked with political powers, historically and especially since the democratic transition (1975-1977)

\section{Political influences}

Refer to coercive external forces arising from the political system, including the government, political parties, and censorship (Picard; Van-Weezel, 2008), and also businessmen and public relations (Mellado; Humanes, 2012). In Spain, the media system has been closely linked with political powers, historically and especially since the democratic transition (1975-1977) (Hallin; Mancini; 2004; Humanes, 1998; Roses; Farias-Batlle, 2013). The development of the digital environment has facilitated access for startups to the news media market because they do not need to rely on the public system of licenses and are not entrenched in a media tradition that positions them in the political environment. In addition, digital journalists seem to act more as independent agents than as representatives of an organization (Agarwal; Barther, 2013), and more like guide-dogs than watchdogs. Faced with this situation, it is important to find out:

RQ1. Are there significant differences between political influences as perceived by journalists working in digital news startups and journalists working in traditional media?

\section{Economic influences}

Refer to pressures in the newsroom due to economic imperatives and commercial considerations (Reich; Hanitzsch, 2013). In this sense, while the traditional media are facing a decline in investment from their sources of funding (APM, 2013; Casero-Ripollés; Cullell-March, 2013), the new digital media face even more economic problems (Bruno; Nielsen, 2012). In this context, it is relevant to know:

RQ2. Are there significant differences between economic influences as perceived by journalists working in digital news startups and journalists working in traditional media?

\section{Influence of professional routines}

Subdivided into professional and procedural by Hanitzsch et al., (2010), arise from the actions journalists carry out re- 
peatedly as part of their work (Shoemaker; Reese, 1996). A multitude of aspects include deadlines and time restrictions, limitation of resources, and the routines of access to information sources. Previous studies point out that the professional routines of digital journalists are different from those carried out by journalists working in traditional media (Becker; Vlad, 2009). The routines of digital media journalists are related to interactivity, technical skills, limited resources to obtain information, and the reduction of time allocated to news production (Agarwal; Barther, 2015; Singer, 1998). All of this makes us wonder:

RQ3: Are there significant differences between the influences of professional routines as perceived by journalists working in digital news startups and journalists working in traditional media?

\section{Organizational influences}

Are those derived from the rules and structures of media organizations, where editorial policy is given priority. This type of influence refers, therefore, to the way power is used within organizations and, consequently, to the decision-making routines (Relly; Zanger; Fahmy, 2015). While traditional media organizations are based on a hierarchical system, many journalists from born-digital news media feel that their organization does not have a formal structure (Agarwal; Barther, 2015). In Spain, a large majority of media outlets are organized into limited-liability companies, while others are registered as associations or cooperative societies (APM, 2013). For this reason, it is important to determine:

RQ4: Are there significant differences between organizational influences as perceived by journalists working in digital news startups and journalists working in traditional media?

\section{Influences of reference groups}

Are derived from the professional realm and the private lives of journalists (Reich; Hanitzsch, 2013). Considering the organization of born-digital news media, in which newsrooms sometimes do not even exist, editing meetings are scarce, interaction with other journalists is almost non-existent, and individualism is predominant (Agarwal; Barther, 2015), it is important to find out:

RQ5: Are there significant differences between the influence of reference groups as perceived by journalists working in digital news startups and journalists working in traditional media?

\section{Method}

\subsection{Sample}

A survey was conducted to collect data from Spanish journalists from both born-digital and traditional media, with funding from, and within the framework of, the Worlds of Journalism Study.

http://www.worldsofjournalism.org

The interviews were conducted by a team of trained interviewers beginning on March 1, 2015 and ending on May 30,2015 , via telephone, in order to ensure the reliability of the answers. The selection of the sample $(n=390)$ was probabilistic as it intended to be representative of the population of journalists in Spain. To be precise, we carried out a multistage (cluster, stratified, and simple random) sampling. The sample size had a confidence level of $95 \%$ and a margin of error of $5 \%$, taking as a reference the estimated population $(\mathrm{N}=18,000)$ for 2014 (Berganza; Herrero; Carratalá, 2016).

A list of national news media companies was created based on a report published by the Madrid Press Association (APM, 2013) and a communication directory created by the Spanish Government (Agenda de la comunicación), in order to carry out the first cluster sampling, using the media company as the sampling unit. A total of 26 born-digital media and 98 traditional media (newspapers, news agencies, radio, TV, and magazines) were selected and stratified by size (large/small) and region. For each large media company, five journalists were randomly selected, and for each small media company, three journalists were randomly selected. This was repeated until the sample of 390 professionals (proportional to the estimated population) was reached: 89 from online media and 301 from traditional media. After being contacted, the journalists who agreed to voluntarily participate in the study were informed about the objectives of the research.

\subsection{Measures}

A scale of 1 to 5 was created to measure the perception of influence: where 1 represents "not influential" and 5 "extremely influential", based on 5 dimensions adapted from a proposal by Hanitzsch et al. (2010):

\section{- political influences, \\ - economical influences, \\ - influence of professional routines, \\ - organizational influences, and \\ - influence from reference groups.}

A number of items were included in the questionnaire to explore each dimension (all used the same scale). The results underwent an exploratory factor analysis (EFA) to establish the validity of each of the 5 proposed constructs (Pérez-Gil; Chacón-Moscoso; Moreno-Rodríguez, 2000; Macía, 2010; Igartua, 2006).

As shown in table 1, each of the 22 items integrated in the questionnaire obtained a significant value on any of the 5 factors suggested by the EFA to be latent structure (explained variance $=60.36 \%, \mathrm{KMO}=0.83$ - Barlett's test $p<0.001$ ). The internal consistency of each construct, measured with Cronbach's Alpha, exhibited adequate reliability in each of the types of influence, following the suggested minimum value in both descriptive studies (0.70) (Cronbach, 1951; Hayes, 2005) and exploratory studies (0.60) (Hair et al., 1999; Robinson; Shaver; Wrightsman, 1991).

\subsection{Analysis}

The interviews were anonymized, transcribed, and coded with the statistical package SPSS (version 21). For each dimension an index was calculated based on the average number of the items detected in the EFA; and these new indicators were used for the descriptive and inferential analyses. An exploratory data analysis (EDA) was performed in 
Table 1. Dimensions of influences through EFA with varimax rotation and reliability tests $(\alpha)$.

\begin{tabular}{|c|c|c|c|c|c|}
\hline Source of influence & Political influence & $\begin{array}{l}\text { Organizational } \\
\text { influence }\end{array}$ & $\begin{array}{l}\text { Influence of pro- } \\
\text { fessional routines }\end{array}$ & $\begin{array}{l}\text { Economic } \\
\text { influence }\end{array}$ & $\begin{array}{l}\text { Influence of ref- } \\
\text { erence groups }\end{array}$ \\
\hline Eigenvalue & 6.109 & 2.427 & 1.515 & 1.213 & 1.213 \\
\hline Explained variance & $27.77 \%$ & $11.03 \%$ & $9.15 \%$ & $6.89 \%$ & $5.52 \%$ \\
\hline Cronbach's alpha (a) & 0.840 & 0.840 & 0.710 & 0.740 & 0.670 \\
\hline Censorship & $0, .45$ & & & & \\
\hline Government officials & 0.750 & & & & \\
\hline Politicians & 0.833 & & & & \\
\hline Pressure groups & 0.809 & & & & \\
\hline Entrepreneurs & 0.682 & & & & \\
\hline Public relations & 0.514 & & & & \\
\hline Army, police and security forces & 0.545 & & & & \\
\hline Immediate boss and editors & & 0.766 & & & \\
\hline Outlet's senior managers & & 0.882 & & & \\
\hline Outlet's owner(s) & & 0.837 & & & \\
\hline Editorial policy & & 0.651 & & & \\
\hline Resources available to obtain information & & & 0.711 & & \\
\hline Deadlines and time constraints & & & 0.675 & & \\
\hline Other media competition & & & 0.507 & & \\
\hline Access to information & & & 0.761 & & \\
\hline Relation with sources of information & & & 0.620 & & \\
\hline Advertisers and commercial interests & & & & 0.648 & \\
\hline Pressure to meet expectations and profits & & & & 0.729 & \\
\hline Audience and market research & & & & 0.777 & \\
\hline Friends, acquaintances and relatives & & & & & 0.789 \\
\hline Colleagues from other media & & & & & 0.755 \\
\hline Co-workers & & & & & 0.709 \\
\hline
\end{tabular}

Note: the analysis includes values $>0.4$

order to detect possible inconsistencies and then a descriptive analysis was conducted to understand the features of the overall sample and of each of the subgroups. To answer the aforementioned research questions bivariate difference tests were executed, particularly the Student's t-test for independent samples and the repeated measures anova, using the bias-corrected bootstrap method with 1,000 samples and confidence of $95 \%$.

\section{Results}

Journalists from online media $(n=89)(M=36.80, S D=10.03)$ are on average significantly younger than journalists from traditional media $(n=301)(M=40.31, S S=8.75), t(387)=$ 3.220, $\mathrm{p}<0.01, \mathrm{BootCl}_{95}=1.17$ to $5.79, d=0.37$. Therefore, journalists from new media $(M=13.10, S D=9.38)$ have fewer years of experience than journalists from the other media $(\mathrm{M}=16.74, \mathrm{SD}=8.64), t(387)=3.390, \mathrm{p}<0.01, \mathrm{BootCl}_{95}=1.53$ to $5.80, d=0.40$. In addition, while men are the majority gender in both groups, gender inequality is much greater among online media journalists, although the association between gender and journalist type is not statistically significant, $\mathrm{X}^{2}$ $(1, N=390)=2.552, p=0.110$. Additionally, a larger percentage of journalists from traditional media enjoy permanent contracts (although not in a significant way, $X^{2}(1, N=390)$ $=1.744, p=0.187)$, and are more likely to be focused on a single work, $\mathrm{X}^{2}(1, \mathrm{~N}=390)=4.070, p<0.05$, and to occupy a writing position, $X^{2}(2, N=390)=9.406, p<0.05$ (table 2). The previous results indicate that there are clear differences between the two types of journalists, with journalists from online media being more likely to be young men with lessexperience, less job security, and better positions within the media companies.

\section{Journalists from online media are more} likely to be young men with less-experience, less job security, and better positions within the media companies

In general terms, the journalists from both groups were mainly influenced by their professional routines $(M=3.60$, $\mathrm{SD}=0.70)$ and organizational variables $(\mathrm{M}=3.39, \mathrm{SD}=1.01)$; and to a lesser degree by economic factors $(M=2.85$, $\mathrm{SD}=1.00)$, reference groups $(\mathrm{M}=2.42, \mathrm{SD}=0.78)$, and political agents $(M=2.20, S D=0.81)$. These differences are statistically significant, $F(4,1540)=281.999, p<0.000$, which means that the factors closest to the profession are the most influential on journalists.

In order to answer the research questions, the average value of each level of influence perceived by journalists from born-digital media was compared with the average value of the journalists from traditional media (table 3). According to the bivariate tests, there are no significant differences in the perception of political influences (RQ1) by journalists from digital news start-ups $(M=2.23, S D=0.80)$ and journalists 
Table 2. Characteristics of the sample

\begin{tabular}{|c|c|c|c|c|c|c|}
\hline & \multicolumn{2}{|c|}{ Journalists from born-digital media } & \multicolumn{2}{|c|}{ Journalists from traditional media } & \multicolumn{2}{|c|}{ Total } \\
\hline & M & SD & M & SD & M & SD \\
\hline Age & 36.8 & 10.0 & 40.3 & 8.8 & 39.5 & 9.2 \\
\hline Years of experience & 13.1 & 9.4 & 16.7 & 8.6 & 15.9 & 8.9 \\
\hline \multirow{2}{*}{ Gender } & Men & Women & Men & Women & Men & Women \\
\hline & $66.3 \%$ & $33.7 \%$ & $58.8 \%$ & $43.2 \%$ & $59 \%$ & $41 \%$ \\
\hline \multirow{2}{*}{ Type of contract } & Temporary & Indefinite & Temporary & Indefinite & Temporary & Indefinite \\
\hline & $15.0 \%$ & $85.0 \%$ & $9.3 \%$ & $90.7 \%$ & $10.3 \%$ & $89.7 \%$ \\
\hline \multirow{2}{*}{ Other paid job } & Yes & Not & Yes & Not & Yes & Not \\
\hline & $19.1 \%$ & $80.9 \%$ & $11.0 \%$ & $89.0 \%$ & $12.8 \&$ & $87.2 \%$ \\
\hline \multirow[t]{2}{*}{ Position } & $\begin{array}{c}\text { Intermediate or } \\
\text { higher }\end{array}$ & Writer & $\begin{array}{c}\text { Intermediate or } \\
\text { higher }\end{array}$ & Writer & $\begin{array}{c}\text { Intermediate or } \\
\text { higher }\end{array}$ & Writer \\
\hline & $41.5 \%$ & $58,4 \%$ & $32.9 \%$ & $67.1 \%$ & $34.1 \%$ & $65.1 \%$ \\
\hline \multirow[t]{2}{*}{ Level of studies } & Postgraduate & $\begin{array}{c}\text { Graduate or } \\
\text { equivalent }\end{array}$ & Postgraduate & $\begin{array}{c}\text { Graduate or } \\
\text { equivalent }\end{array}$ & Postgraduate & $\begin{array}{l}\text { Graduate or } \\
\text { equivalent* }\end{array}$ \\
\hline & $25.9 \%$ & $74.1 \%$ & $23.9 \%$ & $76.1 \%$ & $24.4 \%$ & $75.6 \%$ \\
\hline
\end{tabular}

* $3.3 \%$ of respondents only had high school education

from traditional media $(M=2.19, \mathrm{SD}=0.81), t(384)=-0.436$, $\mathrm{p}=0.663, \mathrm{BootCl}_{95}=-0.25$ to 0.15 . There were also no differences in the perception of organizational influences (RQ2) by digital journalists $(M=3.42, S D=1.07)$ and traditional media journalists $(M=3.38, S D=1.00), t(384)=-0354, p=0.724$, $\mathrm{BootCl}_{95}=-0.31$ to 0.20 . The same happens with the perception of influences of professional routines (RQ3) by digital journalists $(\mathrm{M}=3.60, \mathrm{SD}=0.73)$ and traditional journalists $(\mathrm{M}=3.61, \mathrm{SD}=0.68), t(384)=0.150, \mathrm{p}=0.881, \mathrm{BootCl}_{95}=-0.17$ to 0.17 . In the case of the perception of economic influences (PI4), there were differences between digital journalists $(M=3.02, S D=1.08)$ and traditional journalists $(M=2.80$, $\mathrm{SD}=0.98), t(384)=-1.762, \mathrm{p}=0.079, \mathrm{BootCl}_{95}=-0.47$ to 0.05 . On this last point it is important to mention that, while we cannot speak of a statistically significant difference, the $p$ value $(p<0.10)$ indicates that there would be a difference in trend for the case of the economic influence, which should be subject to further analysis in future research.

However, on average digital journalists $(M=2.62, S D=0.76)$ perceived the reference groups (RQ5) to be more influential in their work in comparison to journalists from traditional media $(\mathrm{M}=2.37, \mathrm{SD}=0.79), t(384)=-2.508, \mathrm{p}<0.05, \mathrm{BootCl}_{95}=$ -0.43 to $-0.07, d=0.31$. The size of these differences can be considered to be small (Cohen, 1988).

While the descriptive analysis shows that both groups differ in their professional and socio-demographic characteristics, the inferential analysis points out that only the influence of reference groups is perceived differently (with higher in- fluence among digital media journalists) (RQ5), while the other types of influence (political, organizational, economical, and professional routines) (RQ1, RQ2, RQ3 and RQ4) are perceived in a homogeneous way by journalists from both new and traditional media.

\section{Discussion and conclusions}

The professional and socio-demographic profile of journalists from born-digital media seems to correspond to the one described by the academic literature on digital journalists in Spain (Martínez-Gutiérrez, 2013; APM, 2013) and Europe (Agarwal; Barter, 2015). These journalists are younger and less experienced, have less job stability, and have positions of higher responsibility within digital media, due in part to the very small size of the majority of digital media companies (Martínez-Gutiérrez, 2013). Digital journalists are mostly men, which may be related to the feminization of unemployment within the profession (APM, 2013).

The higher influence of organizational factors and professional routines over the whole of Spanish journalists, in comparison to political and economic variables and reference groups, is consistent with empirical studies that have been conducted in recent years (Hanitzsch et al., 2010; Hanitzsch; Mellado, 2011; Reich; Hanitzsch, 2013). Although these data appear to move away from the polarized pluralist model (Hallin; Mancini, 2004), they could actually highlight the difficulty of journalists to identify more external and abstract influences as a consequence of the weight of the

Table 3. Influences perceived by journalists in Spain, differentiated in digital and traditional media

\begin{tabular}{|c|c|c|c|c|c|c|}
\hline \multirow[b]{2}{*}{ Perceived influences } & \multicolumn{2}{|c|}{ Journalists from born-digital media } & \multicolumn{2}{|c|}{ Journalists from traditional media } & \multicolumn{2}{|c|}{ Total } \\
\hline & M & SD & M & SD & M & SD \\
\hline Political influence & 2.23 & 0.80 & 2.19 & 0.81 & 2.20 & 0.81 \\
\hline Organizational influence & 3.42 & 1.07 & 3.38 & 1.00 & 3.39 & 1.01 \\
\hline Influence of professional routines & 3.60 & 0.73 & 3.61 & 0.68 & 3.60 & 0.70 \\
\hline Economic influence & 3.02 & 1.08 & 2.80 & 0.98 & 2.85 & 1.00 \\
\hline Influence of reference groups & 2.61 & 0.76 & 2.37 & 0.79 & 2.42 & 0.78 \\
\hline
\end{tabular}


closer and more tangible influences. The greater perception of economic influences over political influences, is probably due to the context of the economic crisis as it affects the media. This crisis is even more acute for born-digital media (Bruno; Nielsen, 2012; Agarwal; Barther, 2015), which would explain that while there is a significant difference between how the influences are perceived in this area, because the crisis of the media is widespread, the results do point to a difference in the trend.

The homogeneous perception of the influence of media routines, on the other hand, would be justified by the digital convergence of traditional media (Hanitzsch; Mellado, 2011; Díaz-Nocy; 2010) as well as by the digital media's adoption of the practices characteristic of traditional media (Bruno; Nielsen, 2012; Agarwal; Barther, 2015). The homogenization of the organizational influences, which is not consistent with the existing literature, and which points out that digital journalism does not have a formal structure and has a less rigid hierarchy than the traditional media (APM, 2013), would require an in-depth study. A possible explanation could be the alleged assimilation by traditional journalists of the editorial policy as part of their work routines, which would result in a lower perception of this type of influence.

If we take into account the youth and inexperience of journalists working in born-digital media, as well as their occupational routines in which learning is less standardized (Agarwal; Barther, 2015), it makes sense that they perceive a greater influence from their professional peers and their personal universe, which become key references when developing their work. Based on the previous findings, it does not seem that a new media logic has emerged in Spanish digital journalism, but it would be necessary to investigate other areas of journalism to be able to affirm this categorically.

In conclusion, our study shows that there are at least 5 clearly differentiated factors in the types of influence that are perceived by journalists and that there are differences between media digital journalists and traditional media journalists. However, except in the case of the influence of reference groups, journalists homogenously perceive political and economic influences (with less weight), as well as the influences of the professional routines and organizational variables (with greater weight), which implies that the new digital media context has not generated different perceptions among journalists with regards to the sources of influence in their work.

The results suggest that more theoretical work must be carried out to better model the factors that influence the activity of journalists and to determine whether new variables can be considered as products of the transformations experienced by the profession of journalism as a result of the digitization of processes. In practical terms, our research seems to suggest that there is a certain mythification in the idea that, because of its emergent character, the new media have professionals that are substantially different from those working in the rest of the media. What we have seen, at least, is that the production conditions of the new journalists are proving to be very similar to those of their peers in traditional media, which suggests that there are similar levels of autonomy in both cases.
One limitation of this study is that constructs such as the influence of professional routines cannot be compared with others developed by previous studies since it includes other sub-constructs that are considered independently in other studies.

Future research in this field should focus on analyzing the objective nature of the factors that influence journalists, i.e. on establishing the differences between the subjective perception of the possible sources of influence and the objective realities that configure the limited autonomy of journalists. This analysis may also provide clues to understand the relationship between journalists' ideologies and perceptions. On the other hand, it is necessary to continue to explore the interrelationships between various levels of influence (how economic and political factors are mediated by media organizations) on the different groups of journalists (national and regional digital media, printed media, television, etc.). These levels of influence can also be reconfigured in light of the new roles that have emerged in new media. Thus, future studies may include specific analyses of how changes in roles (from editor to writer and vice versa; or from journalist to media owner) and in media logics change the perception of external influences.

\section{Nota}

This paper was developed under the framework of the Worlds of Journalism Study. http://www.worldsofjournalism.org

It was funded by the University of Münich (Germany) and with additional financial support from the Ministry on Economy and Competitiveness of Spain (CSO2013- 44874-R).

\section{Bibliography}

Agarwal, Sheetal D.; Barther, Michel L. (2015). "The friendly barbarians: Professional norms and work routines of online journalists in the United States". Journalism, v. 16, n. 3, pp. 376-391.

http://dx.doi.org/10.1177/1464884913511565

Altmeppen, Klaus-Dieter (2008). "The structure of news production: The organizational approach to journalism research". In: Löffelholz, Martin; Weaver, David; Schwarz, Andreas (eds.). Global journalism research: Theories, methods, findings, future. New York: Blackwell, pp. 52-64. ISBN: 978 1405153317

APM (2013). Informe anual de la profesión periodística 2013. Madrid: Asociación de la Prensa de Madrid.

http://www.apmadrid.es/images/stories/informe_ profesion_2013.pdf

Beam, Randal A. (1990). "Journalism professionalism as an organizational-level concept". Journalism monographs, v. 121, pp. 1-43.

Becker, Lee B.; Vlad, Tudor (2009). "News organisations and routines". In: Wahl-Jorgensen, Karin; Hanitzsch, Thomas (eds.). The handbook of journalism studies. New York \& London: Routledge, pp. 59-72. ISBN: 9780805863420 http://www.rasaneh.org/Images/News/AtachFile/30-9-1390/ FILE634600594129473750.pdf 
Benson, Rodney; Hallin, Daniel (2007). "How states, markets and globalization shape the news. The French and US National Press, 1965-97". European journal of communication, v. 22, n. 1, pp. 27-48.

http://dx.doi.org/10.1177/0267323107073746

Berganza, Rosa; Herrero, Beatriz; Carratalá, Adolfo (2016). "La (des)confianza de los periodistas españoles hacia las instituciones públicas a partir del estudio de factores organizacionales". Anuario electrónico de estudios en comunicación social "Disertaciones", v. 9, n. 1, pp. 24-43.

Bruno, Nicola; Nielsen, Rasmus-Kleis (2012). Survival is success. Journalistic online start-ups in Western Europe. Oxford: Reuters Institute for the Study of Journalism. University of Oxford. ISBN: 9781907384080

https://goo.gl/jNizhW

Casero-Ripollés, Andreu; Cullell-March, Cristina (2013). "Periodismo emprendedor. Estrategias para incentivar el autoempleo periodístico como modelo de negocio". Estudios sobre el mensaje periodístico, v. 19, pp. 681-690. http://dx.doi.org/10.5209/rev_ESMP.2013.v19.42151

Cohen, Jacob (1988). Statistical power analysis for the behavioral sciences ( $2^{\text {nd }}$ ed.). Hillsdale, NJ: Erlbaum. ISBN: 978 0805802832

Cronbach, Lee-Joseph (1951). "Coefficient alpha and the internal structure of tests". Psychometrika, n. 16, pp. 297-334. http://kttm.hoasen.edu.vn/sites/default/files/2011/12/22/ cronbach_1951_coefficient_alpha.pdf

Czepek, Andrea; Hellwig, Melanie; Nowak, Eva (eds.) (2009). Press freedom and pluralism in Europe: Concepts and conditions. Bristol: Intellect. ISBN: 9781841502434

Dahlgren, Peter (1996). "Media logic in cyberspace: Repositioning journalism and its publics". Javnost-the public, v. 3, n. 3, pp. 59-72.

http://goo.gl/QOODEZ

http://dx.doi.org/10.1080/13183222.1996.11008632

Deuze, Mark (2005). "What is journalism? Professional identity and ideology of journalists reconsidered". Journalism, v. 6, n. 4, pp. 442-464.

https://goo.gl/ZCeHEj

http://dx.doi.org/10.1177/1464884905056815

Díaz-Noci, Javier (2010). “Medios de comunicación en internet: algunas tendencias". El profesional de la información, v. 19, n. 6, pp. 561-567.

http://recyt.fecyt.es/index.php/EPI/article/view/epi.2010.nov.01 http://dx.doi.org/10.3145/epi.2010.nov.01

Díaz-Nosty, Bernardo (2011). Libro negro del periodismo en España. Madrid: Cátedra Unesco de Comunicación-Universidad de Málaga, Asociación de la Prensa de Madrid. ISBN: 9788487641473

http://www.apmadrid.es/images/stories/Libronegro1soloPDF_ BAJA.pdf

Esser, Frank (1998). "Editorial structures and work in British and German newsroom". European journal of communication, v. 13 n. 3, pp. 375-405.

http://dx.doi.org/10.1177/0267323198013003004
Ettema, James S.; Whitney, D. Charley; Wackman, Daniel B. (1987). "Professional mass communicators". In: Berger, Charles; Chaffee, Michael (eds.). Handbook of communication science. Beverley Hills, CA: SAGE, pp. 747-780. ISBN: 0803921993

Flegel, Ruth C.; Chaffee, Steven H. (1971). "Influences of editors, readers, and personal influences on reporters". Journalism \& mass communication quarterly, v. 48, n. 4, pp. 645-51. http://dx.doi.org/10.1177/107769907104800404

Guallar, Javier (2013). "Prensa digital en 2011-2012". Anuario ThinkEPI, v. 7, pp. 194-199.

http://eprints.rclis.org/19934

Hair, Joseph; Anderson, Rolph; Tatham, Ronald; Black, William (1999). Análisis multivariante (5h Ed). Madrid: Prentice Hall International. ISBN: 9788483220351

Hallin, Daniel C.; Mancini, Paolo (2004). Comparing media systems: Three models of media and politics. New York: Cambridge University Press. ISBN: 9780521835350

Hanitzsch, Thomas; Anikina, Maria; Berganza, Rosa; Cangoz, Incilay; Coman, Mihai; Hamada, Basyouni; Hanusch, Folker; Karadjov, Christopher; Mellado, Claudia; Moreira, Sonia; Mwesige, Peter; Plaisance, Patrick-Lee; Reich, Zvi; Seethaler, Josef; Skewes, Elizabeth; Noor, Dani; Yuen, Kee-Wang (2010). "Modeling perceived influences on journalism: Evidence from a cross-national survey of journalists". Journalism \& mass communication quarterly, v. 87 , n. 1, pp. 5-22.

http://dx.doi.org/10.1177/107769901008700101

Hanitzsch, Thomas; Mellado, Claudia (2011). "What shapes the news around the world? How journalists in eighteen countries perceive influences on their work". International journal of press/politics, v. 16, n. 3, pp. 404-426.

http://dx.doi.org/10.1177/1940161211407334

Hayes, Andrew (2005). Statistical methods for communication science. Mahwah, NJ: Lawrence Erlbaum Associates. ISBN: 9780805854879

Humanes, María-Luisa (1998). “La profesión periodística en España”. Zer, n. 4, pp. 265-278.

http://www.ehu.eus/zer/hemeroteca/pdfs/zer04-12humanes.pdf

Humanes, María-Luisa; Martínez-Nicolás, Manuel; Saperas-Lapiedra, Enric (2013). "Political journalism in Spain. Practices, roles and attitudes". Estudios sobre el mensaje periodistico, v. 19, n. 2, pp. 715-731.

http://dx.doi.org/10.5209/rev_ESMP.2013.v19.n2.43467

Igartua, Juan-José (2006). Métodos cuantitativos de investigación en comunicación. Barcelona: Bosch. ISBN: 978 8497902717

Kunelius, Risto (2007). "Good journalism". Journalism studies, v. 7, n. 5, pp. 671-690.

http://dx.doi.org/10.1080/14616700600890323

Macía, Felipe (2010). "Validez de los tests y el análisis factorial: nociones generales". Ciencia y trabajo, v. 12, n. 35, pp. 276-280.

http://dialnet.unirioja.es/servlet/articulo?codigo=3218921 
Martínez-Gutiérrez, Fátima (2013). “El periodismo emprendedor en España: una alternativa para contextos de crisis". En: Sabés-Turmo, Fernando; Verón-Lassa, José-Juan (coords). Comunicación y la Red. Nuevas formas de periodismo. Zaragoza: Asociación de Periodistas de Aragón, pp. 75-91. ISBN: 9788487175497

http://decimocuarto.congresoperiodismo.com/pdf/libro2013.pdf

McManus, John H. (2009). "The commercialization of news". In: Wahl-Jorgensen, Karin; Hanitzsch, Thomas (eds.). The handbook of journalism studies. New York: Routledge, pp. 218-233. ISBN: 9780803863420

http://www.rasaneh.org/Images/News/AtachFile/30-9-1390/ FILE634600594129473750.pdf

Mellado, Claudia; Humanes, María-Luisa (2012). “Modeling perceived professional autonomy in Chilean journalism". Journalism, v. 13, n. 8, pp. 985-1003.

http://dx.doi.org/10.1177/1464884912442294

Pérez-Gil, José; Chacón-Moscoso, Salvador; Moreno-Rodríguez, Rafael (2000). "Validez de constructo: el uso de análisis factorial exploratorio-confirmatorio para obtener evidencias de validez". Psicothema, v. 12, n. 2, pp. 442-446 http://www.psicothema.com/pdf/601.pdf

Picard, Robert G.; Van-Weezel, Aldo (2008). “Capital and control: Consequences of different forms of newspaper ownership". International journal on media management, v. 10, n. 1, pp. 22-31. http://www.robertpicard.net/PDFFiles/capitalandcontrol.pdf http://dx.doi.org/10.1080/14241270701820473

Plaisance, Patrick-Lee; Skewes, Elizabeth A.; Hanitzsch, Thomas (2012). "Ethical orientations of journalists around the globe: Implications from a cross-national survey". Communication research, v. 39, n. 5, pp. 641-661.

http://dx.doi.org/10.1177/0093650212450584

Preston, Paschal (2009). Making the news: Journalism and news cultures in Europe. London: Routledge. ISBN: 978 0415461887

Reich, Zvi; Hanitzsch, Thomas (2013). "Determinants of journalists' professional autonomy: Individual and national level factors matter more than organizational ones". Mass communication and society, v. 16, n. 1, pp. 133-156. http://dx.doi.org/10.1080/15205436.2012.669002
Relly, Jeannine E.; González-de-Bustamante, Celeste (2014). "Silencing Mexico: A study of influences on journalists in the Northern states". International journal of press/ politics, v. 19, n. 1, pp. 108-131.

http://dx.doi.org/10.1177/1940161213509285

Relly, Jeannine E.; Zanger, Margaret; Fahmy, Shahira (2015). "Democratic norms and forces of gatekeeping: A study of influences on Iraqui journalist's attitude toward government information access". Journalism and mass communication quarterly, v. 92, n. 2, pp. 346-373.

http://dx.doi.org/10.1177/1077699015573195

Robinson, John P.; Shaver, Phillip R.; Wrightsman, Lawrence S. (1991). "Criteria for scale selection and evaluation". In: J. Robinson, P. Shaver \& L. Wrightsman (eds.) Measures of personality and social psychological attitudes. San Diego: Academic Press, pp. 1-16. ISBN: 9780125902441

Roses, Sergio; Farias-Batlle, Pedro (2013). “Comparison between the professional roles of Spanish and U.S. journalists: Importance of the media system as the main predictor of the professional roles of a journalist". Comunicación y sociedad, v. 26, n. 1, pp. 170-195.

http://dadun.unav.edu/bitstream/10171/35446/1/20130807134923. $p d f$

Shoemaker, Pamela J.; Reese, Stephen D. (1996). Mediating the message: Theories of influence on mass media content ( $2^{\text {nd }}$ ed.). White Plains, NY: Longman. ISBN: 0801312515 https://journalism.utexas.edu/sites/journalism.utexas.edu/ files/attachments/reese/mediating-the-message.pdf

Singer, Jane B. (1998). "Online journalists: Foundations for research into their changing roles". Journal of computer-mediated communication, v. 4, n. 1.

http://dx.doi.org/10.1111/j.1083-6101.1998.tb00088.x

Singer, Jane B. (2007). "Contested autonomy: Professional and popular claims on journalistic norms". Journalism studies, v. 8, n. 1, pp. 79-95.

http://dx.doi.org/10.1080/14616700601056866

Voakes, Paul S. (1997). "Social influences on journalists' decision making in ethical situations". Journal of mass media ethics, v. 12, n. 1, pp. 18-35.

http://dx.doi.org/10.1207/s15327728jmme1201_2
PRÓXIMOS TEMAS

\begin{tabular}{|c|c|}
\hline Número & Mes-año \\
\hline 25,3 & May 2016 \\
\hline 25,4 & Jul 2016 \\
\hline 25,5 & Sept 2016 \\
\hline 25,6 & Nov 2016 \\
\hline 26,1 & Ene 2017 \\
\hline 26,2 & Mar 2017 \\
\hline 26,3 & may 2017 \\
\hline
\end{tabular}

Tema

Metamedios y audiencias

Datos

Evaluación de la ciencia

TIC para información y comunicación

Información biomédica

Ética, investigación y comunicación

Información pública
Envío textos

30 marzo 2016

20 mayo 2016

10 julio 2016

10 sept 2016

10 nov 2016

10 enero 2017 